\title{
ASSESSING MALAYSIA'S CREATIVE INDUSTRY: PROGRESS AND POLICIES IN THE CASE OF THE FILM INDUSTRY
}

\author{
Lee YOONG $\mathrm{HON}^{1}$, Ruth LIM SHEAU YEN ${ }^{2}$ \\ ${ }^{1}$ University of Nottingham Malaysia Campus, Nottingham University Business School, \\ Jalan Broga, 43500, Selangor, Malaysia \\ ${ }^{2}$ Heriot-Watt University, School of Social Sciences, No. 1 Jalan Venna P5/2, Precinct 5, \\ 62200 Putrajaya, Malaysia
}

Received 24 January 2019; accepted 16 June 2019

\begin{abstract}
This paper explores the performance of local movies at the Malaysian box-office circuit to ascertain and analyse the extent of the reported improvements of the sector - it is hoped that the findings can provide a more objective assessment of the state of local films and the policies that have been aimed at cultivating improvements in the sector. Overall, the findings indicate that the local movie industry is still a long way from establishing a strong foothold even in its own domestic market.
\end{abstract}

Keywords: box-office, cultural policy, foreign movies, local movies, Malaysia film industry.

\section{Introduction to the Malaysian film industry}

The Malaysian film industry (FI) has grown substantially since the nation's early pre-independence days. Government initiatives and policies have helped, to a large degree, with the industry's output registering encouraging figures in recent years. The national agency that oversees the development of the local industry is the National Film Development Corporation Malaysia (or FINAS, the Malay language acronym) - its mission, amongst others, the internationalisation of the local creative industries (CIs) and strengthening of the facilities for film-making ${ }^{1}$. In recent years, the government initiatives have led to not only many foreign film-makers (FFMs) shooting movies in Malaysia but also the export of local expertise and work on film-making and creative output $(\mathrm{CO})^{2}$. From the 2013 Economic Transformation

\footnotetext{
1 FINAS was established in 1981 under the Ministry of International Trade and Industry (Malaysia) although as of 2013, it is now under the purview of the Malaysian Communications and Multimedia Commission. Its main goal is to oversee and ease the progress of the Malaysian FI (Finas, 2016).

2 FINAS has played an active role in attracting international film-makers to shoot their movies in Malaysia in addition to assisting in promoting local movies (LMs) abroad. In 2013, a 30\% tax/cash rebate scheme for film production activities was introduced, both for local and foreign players while the government's cooperation with Pinewood Group led to the setting up of Pinewood Studios in Iskandar Malaysia (state of Johor in Malaysia) (cited in Oxford Economics, 2013).
}

*Corresponding author. E-mail: lee.yoong-hon@nottingham.edu.my 
Programme report, the Malaysia CI saw RM564.89 million worth of export revenue ${ }^{3}$. Not surprisingly, the contribution to the economy by this sector has been impressive - the total economic contribution of film and television to the country's gross domestic product is estimated to be RM5.6 billion while providing up to 59.800 jobs (Oxford Economics, 2013). Further, the construction of Pinewood Studios in Iskandar, in the state of Johor, represents another milestone in Malaysia's ambition of becoming a hub for film-making. A massive integrated media production studio facility which opened its doors in 2014, the project is a joint venture between Pinewood Studios and the local government linked corporation, Khazanah Nasional $^{4}$. In essence, the Malaysia CI covers a wide range of industrial categories, namely the creative multimedia, the creative arts and culture and finally, the creative cultural heritage $(\mathrm{CCH})$ (each of which consists of further sub-sectors, with 14 in total) - the FI is placed under the first category and is regarded as a key industry in the constellation of the CI in Malaysia despite the explicit emphasis by the National Creative Industries Policy (NCIP) on the digital media sector (Barker \& Yuen Beng, 2017).

Globally, the FI has been and continuously to be massive - theatrical box-office alone hit US\$41.1 billion in 2018 with the global entertainment market (EM) and home EM growing 9 and $16 \%$ respectively in 2018. In terms of theatrical box-office growth, the North American (NA) market grew 7\% while China and the Asia-Pacific (AP) region registered 12 and 5\% respectively. As for the number of theatrical screens' growth globally, 2018 recorded a 7\% growth (Ortman, 2019). To provide some context, global 2018 economic growth rate are forecasted by the International Monetary Fund to grow 3.7\%; United States (US) at 2.9\%, China at 6.6\% while Malaysia, 4.7\% (bnm.gov.my, 2018). Malaysia's box-office-wise, the total collected for local movies (LMs) in 2017 was RM56.76 million while in 2018, over RM150 million (Malek, 2019). This represents a box-office growth of growth more than $160 \%$ ! While not all regions or countries have experienced steady growth in the sector in recent times (e.g., Europe, Middle East and Africa as whole recorded -3\% growth in 2018 while Latin America, -22\%), AP (in particular China) has been impressive. In fact, Asian countries continues to grow in this sector - China (top), Japan and South Korea (SK) among the 4 top international box-office markets (for 2018) while Malaysia was placed at respectable 19th spot (mpaa.org, 2018).

According to FINAS, there were 80 LMs produced in 2015 as compared to only 28 in 2008. Similarly, the revenue from LMs have made tremendous improvements in the last decade, from an annual nominal box-office of RM29.62 million in 2008 to RM83.06 million in 2016, with an industry record of RM126.49 million in 2011 (Finas, 2019c). In addition, the box-office receipts for some of these LMs have been commendable despite the continuous influx of foreign movies (FMs), especially those from Hollywood. For example, the locally produced movie, The Journey (director Chiu Keng Guan, 2014), broke records locally in 2014, taking over RM17.17 million at the local box-office, the sixth highest grossing LM of all-time (as of May, 2019). The fact that The Journey is a Cantonese movie speaks volume for the industry as the LM has always been Malay movies that are targeted at the Malay

\footnotetext{
${ }^{3}$ From Deputy Minister's of Communications and Multimedia (Malaysia) Jailani Johari's speech during the report's launch (Koay, 2014).

${ }^{4}$ Spread over 50 acres, the studio offers up to 10.000 sq. $\mathrm{ft}$ of film stages, $24.000 \mathrm{sq}$. $\mathrm{ft}$ of television studios and various other supports for film-making.
} 
ethnic group in the past. In fact, 3 other local Chinese-language movies also made the top 30 highest grossing LM list while 3 more in the top 40 - suggesting increased diversity in the industry and also a growing preference for LMs among the other ethnic groups besides the Malay community ${ }^{5}$. This is encouraging in that, in the past, movies from Hong Kong and India have always been the preference for the local Chinese and Indian ethnic groups, as are Hollywood movies as well.

However, despite the encouraging improvements among the local players, the industry is lagging when compared to international movies especially those from Hollywood which boasts of massive production costs and extensive marketing promotions. Production costs in excess of US $\$ 100$ million are not uncommon while total costs, inclusive of marketing and promotion, can easily be double that figure. As such, box-office achievements from such movies easily dwarf the collections of LMs in comparison ${ }^{6}$. This is not surprising considering that the majority of movie patrons tend to skew towards the younger audience and this group is more likely to appreciate works of popular culture and action-driven pieces, an area in which Hollywood moviemakers easily dominate. Liew Chee Kit and Lee Weng Chuan (2012) found that the younger audience in Malaysia prefers Hollywood movies compared to local ones since the former provides greater gratifications - i.e., superior technological innovation (special effects), celebrity actors, storylines and so on.

Jamaluddin Aziz, Hasrul Hashim, and Faridah Ibrahim (2014), elicited responses from 10 local film-makers (LFMs)/producers and also narrowed in on two recurring themes plaguing the local industry - firstly, the issue of quality, this transcends on issue ranging from script and storyline quality to production and technological value quality, and secondly, the issue of creativity. Herwina Rosnan and Zarith Delaila Abdul Aziz (2012) meanwhile, identified several challenges faced by the local FI - these include having a small domestic market (DM), little restrictions in FMs' entrant to the local market (LMA), and also the limited success of indigenous movies locally that eventually hampers any potential success overseas. The issue of having a small LMA is also echoed by Aziz et al. (2014), in addition to the country's multi-ethnicity background (which comprises of the Malays ${ }^{7}$, Chinese, Indians, the local indigenous group and other minorities) that further divides the audience into multiple groups - the local working class Malays making the bulk of the audience of the LMs, which itself is largely made up of Malay-language movies. Meanwhile, the issue of different ethnic film-makers, catering to different segments of the market poses another challenge as far as the market size for their movies are concerned. While Malaysian Chinese film-makers continue targeting the local Chinese community, the Malaysian Indian film-makers, in contrast, have gone more mainstream, i.e., making Malay language movies to cater to the local Malay market, which itself comprise of lower and middle class Malays (Aziz et al., 2014). This is perhaps unsurprising, given that the less mainstream Indian movies, despite their critical acclaim achievements, generally do not do well in the box-office. For example, the

\footnotetext{
${ }^{5}$ Ah Beng The Movie: Three Wishes (director Silver Chung, 2012), Nasi Lemak 2.0 (director Namewee, 2011), Great Day (director Keng Guan, 2011) are the three local Chinese-language movies that made the top 30 list of highest grossing local movies while The Kid from the Big Apple (director Jess Teong, 2016), Once Upon a Time (director Chung, 2013) and Think Big Big (director Keng Guan, 2018) are the three others which made the top 40 list (Finas, 2019d).

${ }^{6}$ Local films do not stack up both in terms of budget and marketing strategy. There are funds available for promotional purposes-up to RM300.000 per film but the selection process is very stringent (Aznam Shah, 2017).

7 The dominant group accounting for more than $50 \%$ of the population of Malaysia.
} 
well-reviewed Jagat (director Shanjey Kumar Perumal, 2015), made only RM224.370, placing it 42 nd position among $80 \mathrm{LMs}$ in 2015 . Overall, the local film (LF) market continues to be dominated by Malay movies, with Mandarin and Tamil movies only making up 22\% and 12\% of the total locally-made movies respectively in 2015 (Finas, 2019c).

Given the dearth of academic research papers on the FI in Malaysia, it would be interesting to assess some of the recent developments in the sector. The paper aims to achieve this and will begin by describing the national agency that is in charge of nurturing the industry and providing a brief historical account of some of the key policies. Next, it will analyse the performance of the industry using data on the industry's output and fact-based assessments, i.e., providing a critical discussion on the local FI using "stylised data".

This paper comprises of five sections. Introduction section gives a brief and general introduction on the local FI and its performance in general. Section 1 provides a write-up on the national agency in charge of developing the FI - FINAS and a brief historical account of the policies pursued over the years. Section 2 is the section describing the type of data, the sources and the fact-based assessment approach employed by the paper. Section 3 covers the reporting of the findings while section 4 provides a critical assessment (of the industry and policies). The last section is for the conclusions.

\section{Government agencies and policies on the film industry in Malaysia}

The government agency responsible for the FI of Malaysia is the FINAS. Originally established in 1981 under the National Film Development Corporation Act 1981 (or, Akta Perbadanan Kemajuan Filem Nasional Malaysia 1981 in the Malay language), FINAS was then placed under the Ministry of International Trade and Industry (Malaysia) but subsequently placed under the Ministry of Culture, Arts and Heritage (Malaysia) in 2004. Later on, it came under the Ministry of Information, Communication and Culture (Malaysia) before eventually being placed under the Ministry of Communication and Multimedia in 2013. The main objective of FINAS is to encourage, preserve and ease the progress of the nation's FI. In order to achieve this, the agency lists out many strategies including making Malaysia's creative content acceptable domestically and having the ability to compete at both the regional and international arenas $^{8}$. Since its inception, it has introduced many initiatives to develop the country's FI, from workshops ${ }^{9}$ to financial assistance and other support services. For example, the financial assistance is not restricted only in the case monetary but also access to film-making resources (both capital and labour). FINAS has also in the past, made available, assistance incentive schemes in the form of payment, loans or other types of aid to

\footnotetext{
8 The full list of visions and strategies of the agency can be found at its introduction webpage (Finas, 2019a).

9 FINAS has organised many workshops and forums over the years, inviting key figures that included top academics in film making - for example, in 1989, Professor Peter Gerdes, then the Head of the School of the Arts and Media (Department of Theatre and Performance) at University of New South Wales was invited to give talks at a FINAS-organised forum (FINAS Malaysia Annual Report, 1989, see Finas, 2018).
} 
any organisations (or bodies ${ }^{10}$ ) or individuals ${ }^{11}$ whose involvement in any activities which have had a positive impact on the development of the local FI. Beneficiaries of such financial assistance or awards have also included film students as well.

\subsection{Recent major incentives and policies (2013-present)}

The Malaysian government aims to make Malaysia a film hub (in line with FINAS' mission of internationalising the local creative market and shooting locations), with tax breaks for foreign and domestic film productions - in 2013, a new tax rebate scheme was introduced with local and foreign film (FF) productions being eligible for a 30\% tax rebate for both production and post production activities (Oxford Economics, 2013). This scheme, known as "FIMI" (acronym for Film in Malaysia Incentive) is available for any film productions and post-production activities, with one of its objectives being to encourage LM producers to produce high quality creative content for both domestic and international markets (IMs) (FIMI, 2017). In any case, this additional financial scheme is essentially an additional financial incentive to spur the country's creative content production and is open to both production and postproduction activities ${ }^{12}$.

\subsection{Other major initiatives (1982-present)}

Next, a mandatory screening scheme (or, Skim Wajib Tayang in Malay) was introduced by the government to ensure all LFs are screened in local cinemas - all LFs, registered with this scheme must be shown for at least 2 weeks ${ }^{13}$. Enforced on June 2005, the ruling, nonetheless, includes several clauses which entitles the exhibitor to make certain changes when deemed valid - e.g., while it is compulsory to screen the film in the biggest hall in the cinema, the exhibitor could move it to a smaller one if the number of viewers fall below $15 \%$ of the capacity of the biggest hall after the first three days. Also, the exhibitor can stop the film's run (even if it is below 14 days) if capacity issue arises but must submit a report to the film's producer and FINAS. Recent changes to this initiative includes a move to a smaller hall if the number of viewers fall below 15\% of the capacity of the biggest hall after the first four days as opposed to three in the earlier version while a five-times screening a day replaces the original four-times a day (Begum, 2016).

\footnotetext{
${ }^{10}$ For example, the Malaysian Film Producers Association (MFPA, Persatuan Penerbit Filem Malaysia, in Malay language).

11 In the past, film students from local universities and the Malaysia Film Academy (Akademi Filem Malaysia, in Malay language) have been the recipients of such monetary aid.

${ }^{12}$ For LFM, the project must have a minimum expenditure of RM2.5 million while for a foreign one, a minimum of RM1.5 million if involved solely post-production activities or RM5 million if it is combined with both production and post-production activities. For FF projects, at least $30 \%$ of the crew must be local (FINAS).

13 This scheme was first introduced in November, 1982. This was an arrangement between FINAS and the exhibitors, with the aim of giving some minimum amount of screen time to local films. The duration set then was for a week with the subsequent screen run subjected to collections - the run could be halted should the collections fall below a "hold over figure". The withdrawal of a film can happen less than week in the case of screenings in "average" size towns if the collections fell below the "hold over figure" for three consecutive days. The scheme was tweaked in 1991 - the minimum days was set at 7 days for screenings at big town and 3 days for screenings in small towns. Similarly, the run after the minimum seven and three days threshold respectively can be halted should the daily collections fall below the "hold over figure" (see FINAS Malaysia Annual Report, 1983, 1991, 1998 in Finas, 2018).
} 


\section{Data}

We compiled and utilised secondary quantitative data for our analysis of the performance of the local FI. The quantitative data analysis was drawn from figures and statistics provided by two sources, one, Box Office Mojo (2019a), and two, FINAS (2016), which is the webpage for the FINAS ${ }^{14}$. The former is well cited in many papers on the motion picture (MP) industry although the figures (box-office) are quoted in US dollars. As for the FINAS website, the data included the number of screens, local box-office collections, the number of days screened and production cost. These figures are analyse and cross-reference to reports and articles on the LM industry in order to provide a credible assessment of the sector and the impact of the local policies. Finally, we also went through the annual reports from FINAS (1983-2016) to verify and report the relevant figures, policies and developments on the LF sector, especially for the pre-2000 period.

\section{Assessing the data}

Overall, the LM industry has certainly come a long way, from an annual LFs of only 17 in 1989, the amount of movies being released annually has increased steadily since then, with an industry high of 81 in 2014 (see Figure 1). In terms of admissions and box-office takings, LMs have seen dramatic rises too - from an annual attendance of 4 million in 2006 to 13.14 million in 2011, with an average annual attendance of 7 million from 2006-2016. Revenuewise, in 2006, the local industry made RM29.6 million and by 2016, almost tripled the figure, with RM83 million. 2011 remained the industry high, with a staggering RM126.5 million collected (data from Finas, 2019b). Finally, from just 83 number of cinemas in the country in 1986 (assuming one screen per cinema, only 83 screens ${ }^{15}$ ), the number has rose many folds over the last three decades, as of 2017, a total of 147 cinemas (cineplexes) which equates to 1017 screens across the country ${ }^{16}$.

Nonetheless, closer analysis of the data reveals a slightly different story. In many ways, the performance of the Malaysia FI falls short when assessed in a broader context, i.e., when looking at the market as whole, complete with FMs. In this context, imported FMs, especially those from Hollywood easily outperformed the Malaysian movies at the local box-office. While this is not entirely surprising (given many reasons, some of which would be discussed later), such trends strongly suggest that the LM industry may require further attention (in additional to existing ones) from policymakers despite the massive inroads that it has achieved in recent years. In terms of diversifying and deepening the industry, the regulators has done a commendable job as the industry have shown ample improvements in terms of creativity,

\footnotetext{
$\overline{14}$ Data for those before 2008 were taken from the published FINAS Malaysia Annual Reports (1983-2007) (see Finas, 2018).

15 Based on authors' own assertion/observation on the pre-cineplex era in the 1980s.

161986 figure quoted from FINAS Malaysia Annual Report 1988 (see Finas, 2018); current figures from FINAS (2016).
} 


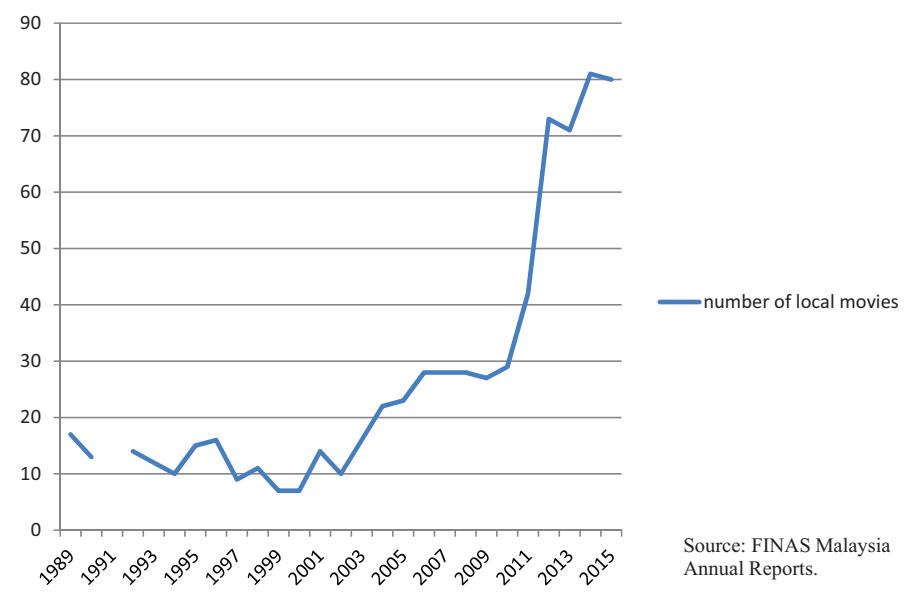

Figure 1. Annual number of local movies (1989-2016) (source: FINAS Malaysia Annual Reports (1989-2007) (see Finas, 2018; FINAS, 2019c)

Notes: The annual figures are compiled by the authors using figures from the FINAS Malaysia Annual Reports (1989-2007) (see Finas, 2018); the 2008-2016 figures from the FINAS (2019c) website. For the data from 1989-2007, the total number of movies produced annually includes both the list of movies registered under the mandatory screening scheme and those that are not. For e.g., in 2004, 21 movies were registered while one was not while in 2005, there were 23 movies but 3 of them were not registered with the scheme. In 2004 and 2007, the number of films counted is 28 for both years but the figures include those that are not registered with the scheme -8 films in 2006 and 7 in 2007 respectively. In 1994, 21 films were produced but only 10 were screened. Finally, there were no figures for 1991 as the annual report for 1991 was not available.

innovation, capital investments and skilled technical human capital ${ }^{17}$. Nonetheless, despite such progress, regulators may need to look into policies that can help protect the revenues of LFs from the invasion of FMs. The fact that there are virtually no barriers for FFs (other than adhering to/subjecting to censorship by FINAS - with issues of excessive violence and sexual content being the main basis for rejection in most cases) has led to an industry flooded with FMs.

In terms of market competition, the influx of FMs is huge compared to the local output, with an average of 200 movies annually from 2008 to 2016. In fact, the percentage of FMs over the total movies screened in cinemas locally during the said period is in excess of $65 \%$ every year, with a peak of $91 \%$ in 2008 (see Table 1). As such, when assessed against imported movies, the improvements in the LFs' output appear less stellar in many ways. One obvious area is the output - the average number of LMs released is very small when compared to FMs - about 54 annually from 2008-2016, which is only about one-fourth of the amount of FMs (200) (see Tables 1,2).

We compare the top LMs against FMs' grossing to see how the local fares performed when compared to their foreign counterparts annually from 2008-2016. Adjusting for exchange

\footnotetext{
17 According to the Oxford Economics (2013) report on the film and television industry of Malaysia, the development of the animation industry has been very successful, with several animated MPs even exported and produced with other countries like US and SK. Also, FINAS have had a hand in helping the distribution of Malay movies in film markets in Europe while policies have been rolled out to entice FFMs to make movies in Malaysia.
} 


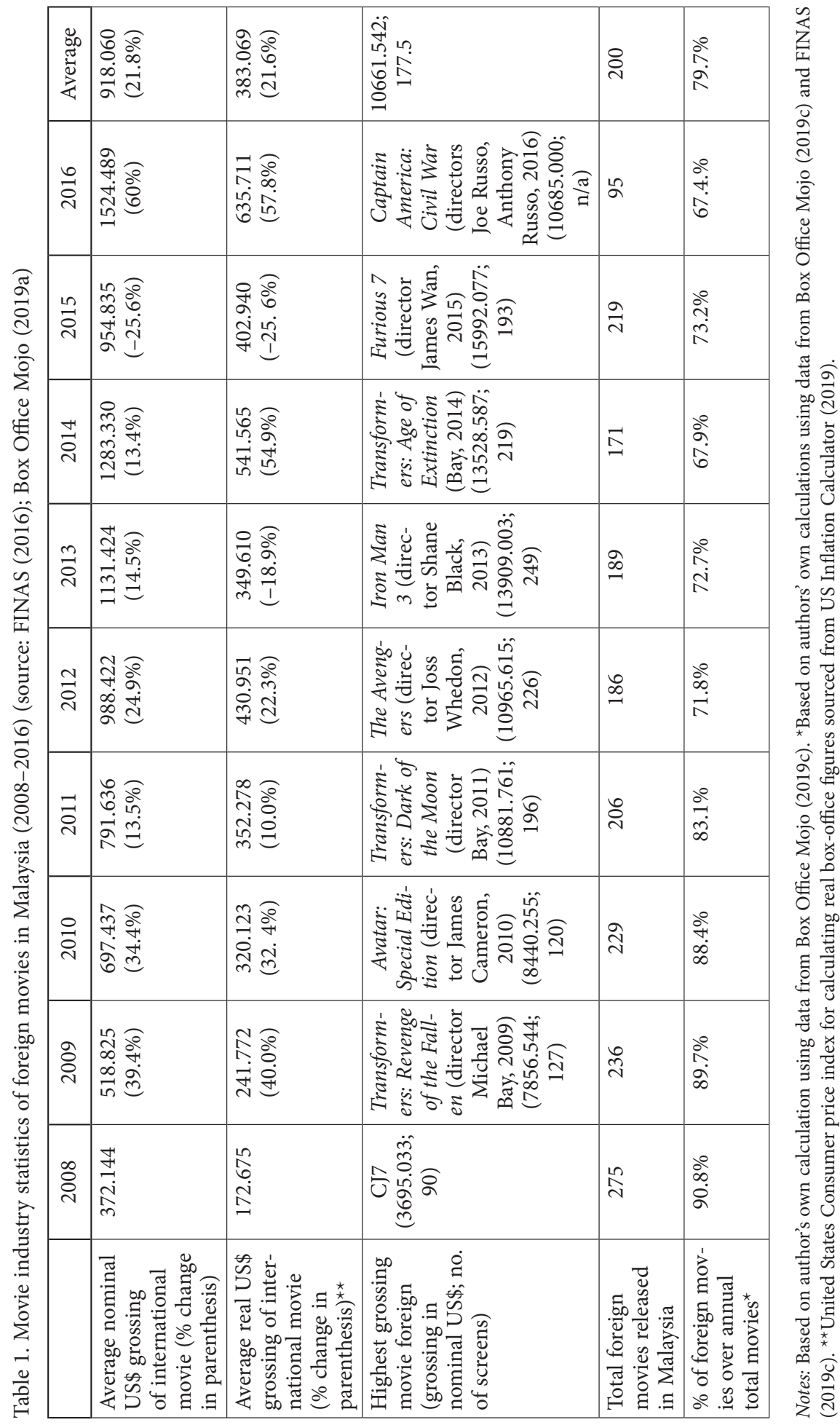




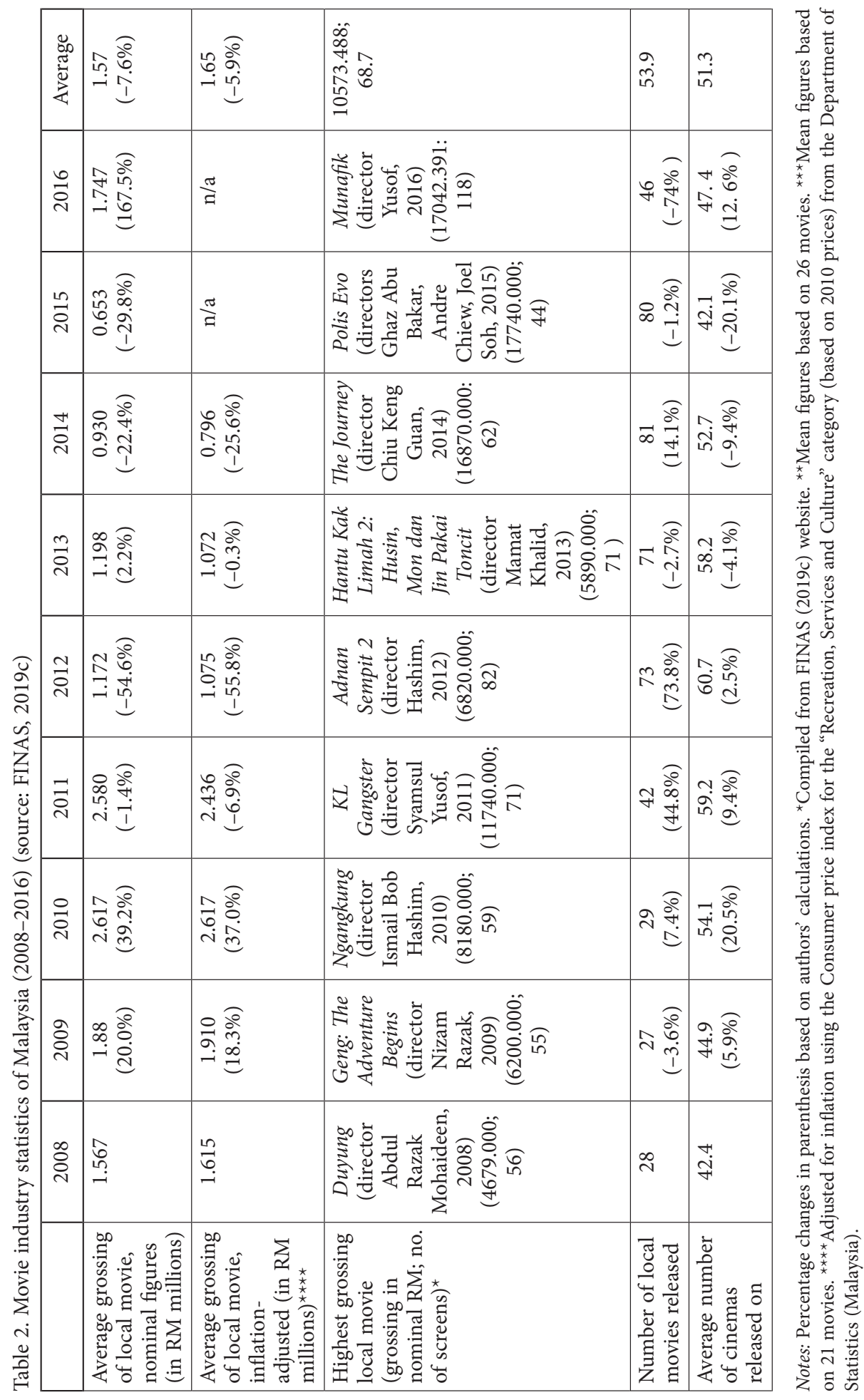


rate differential, only 4 LMs made the top ten listing of the highest grossing movies in the country annually from 2008-2016 - KL Gangster (director Syamsul Yusof, 2011) made the top ten list in 2011 while Munafik (director Yusof, 2016), Ola Bola (director Keng Guan, 2016) and BoBoiBoy: The Movie (director Nizam Razak, 2016) all made it for $2016^{18}$. On average, from 2008-2016, LMs made RM1.57 million annually but FMs made US\$918.060. Even with the most conservative exchange rate used during the period (i.e., Malaysian ringgit traded at RM2.9665 to US\$1 on 29th July 2011 (XE, 1995-2019)), FMs still made almost double on average - this on an average of 200 movies compared to the local's average output of 54 movies $^{19}$ ). Further, the average LM annual grossing (both in nominal and real terms) has begun showing a downward trend post-2010 but the mean annual grossing for FMs has been rising every year from 2008 except 2015 (see Tables 1, 2).

Next, we look at the issue of length of run at the cinema for movies. Essentially, box-office revenue is positively correlated with this - the longer legs a movie has, the more it can earn. In the NA market, the usual movie contract run is about 4-8 weeks with Arthur De Vany and W. David Walls (1999), professing that a movie's box-office potency is 35, 19 and $12 \%$ respectively in its first three weeks' run. In this respect, the run at the cinema for most LMs is rather short - on average, from 2012-2016, is just under 3 weeks. In fact, almost $40 \%$ of the LMs have had a run of 2 weeks of less at the box-office in $2015^{20}$. If we follow the assertion in Vany's and Wall's paper, 4 out of 10 movies that are released in Malaysia are at best, only able to recoup about half its box-office potential. More importantly, although the number of LMs produced has seen substantial increase (with the exception of 2016), the number of movies with a screen run of 2 weeks or less has been steadily increasing every year from 2012-2016. All these suggest faint interest in many of the LMs released - hence their short theatrical run and consequently, too small a window of opportunity to make a significant impact at the box-office. Tangential to this point is the number of screens released - also a significant factor in a movie's box-office receipt potential (see King, 2007; Yoong Hon, 2014) but also one that presents another challenge for LMs - on average, LMs are released only in 52 cinemas. Given that the total number of screen (in all cinemas) in the country is 1019 (figures from Finas, 2016), this represents only about 5\%, assuming a highly plausible scenario of one screen per cinema ${ }^{21}$.

In terms of the market share for the 10-year period from 2006-2016, LMs' share is about $12 \%$, while FMs took the rest - with English movies dominating with a share of $68 \%$ while Chinese language and Indian language FMs taking in 12 and 6\% respectively. This shows that the LMs still lag far behind FMs - the fact that Chinese FMs have a similar share indicate that a majority of the local Chinese (and to some extent, the other ethnic groups as well ${ }^{22}$ )

\footnotetext{
${ }_{18}$ When comparing the performance of FMs against local ones, the medium for the comparison was RM thus the relevant FMs' box-office in US were converted to RM using the most conservative value in the month they were released using exchange rate figures from XE 1995-2019. KL Gangster was ranked 9th in 2011 while Munafik, Ola Bola and BoBoiBoy: The Movie were ranked 7th, 8th and 10th respectively in 2016.

19 Average figures from are calculated from Table 3 annual figures.

20 Authors' own calculation based on annual data from FINAS (2016).

${ }^{21}$ Based on anecdotal observations by the authors.

${ }^{22}$ Hong Kong Kung fu action films are universally popular in Malaysia especially those involving Kung fu icons like Jackie Chan and Donnie Yen.
} 
still prefers to watch Chinese FMs (see Figure 2). When assessed in terms of growth, LMs have shown respectable improvement, with movie attendance showing steady increase from 2006-2016. While this is encouraging but other FMs also demonstrated similar if not an even bigger percentage growth - the English language FMs and Indian FMs having the biggest increase (see Figure 3).

Finally, data in industry also support the notion of the Malaysia FI subscribing to a winner-takes-all sort of market - a market that is characterised by positive information feedback which Vany and Walls (1996) explain as one which the bulk of the revenue of the sector would rest on only a few winners, i.e., a few hit movies garnering a significantly larger share of the box-office gross compared to the big pool of failures. The easy dominance of top Hollywood movies at the local box-office suggest that the Malaysia market also subscribe to such notion, with the winners being in the hands of few top offerings (almost exclusively Hollywood tent-poles) while the losers, heavily made up of the local fares (and some foreign ones as well). To provide some perspective, the total box-office taking of all $80 \mathrm{LMs}$ released in 2015 was RM51.6 (data tabulated from Finas, 2016); but Furious 7 (director James Wan,

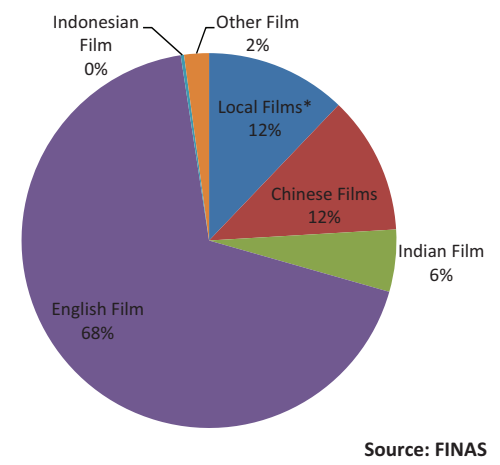

Figure 2. Market share of local movies versus foreign movies (2006-2016) (source: FINAS (2019b) (figures were compiled from information from the FINAS (2016)

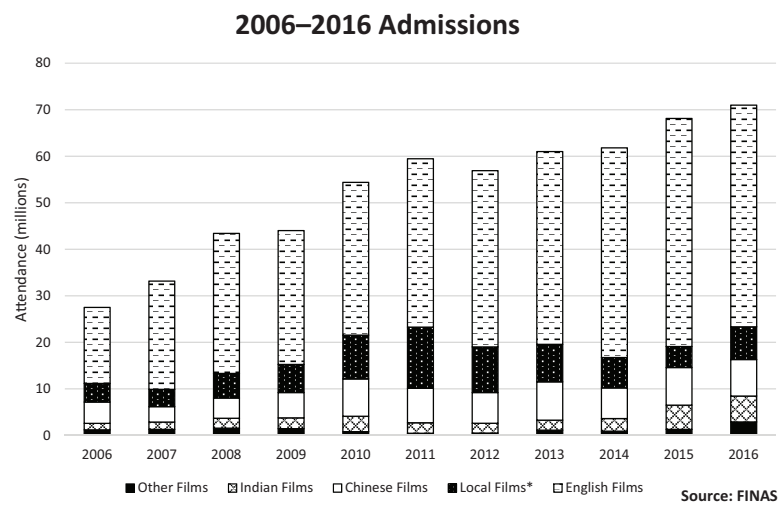

Figure 3. Admissions according to type of movies (2006-2016) (source: FINAS (2019b) (figures were compiled from information from the FINAS (2016) 
2015) alone made RM 55 million that year (Aznam Shah, 2017). According to Film Business Asia, while local releases increased to 84 in 2014, their market share was only $10.2 \%$ (revenue-wise), and 9.48\% (admission-wise) (Aznam Shah, 2017). In fact, from 2006-2016, LMs' market share of the local box-office was only $12 \%$ (see Figure 2).

\section{Further discussions}

Overall, data on the FI in Malaysia reveals a somewhat more pessimistic picture than casually observed. While it is fair to say that the industry has improved, both in terms of productivity and technical achievements, the ability of LFs to compete are questionable. There are several reasons for this, with the issues originating both internally (the local industry's competency) and externally (the competition from foreign players). In the case of the former, the quality of the LFs that are churned out is seen as the problem - this extends to the quality (lack of) of the script, production values, technology and the actors (Aziz et al., 2014) while in the case of the latter, the vastly superior imported films continue to dominate. It does not help that the sector has little restrictions as far as imports are concerned. While an open market competition is ideal, this has, unfortunately stifled the market of LFs significantly. To make matters worse, the Malaysia market is considered a very small market, thus making it even more difficult for LFs to see huge profits. For films to be successful internationally, they must first be successful locally, according to Colin Hoskins and Stuart McFadyen (1991) and Harold L. Vogel (2011). If this true, then it is not surprising that few LFMs have been successful overseas. In fact, films from Hong Kong (and in recent times, China) and Bollywood are just as dominating - e.g., the fact that in the past, Bollywood films, in Hindi, used to be broadcasted on Malaysian television without the aid of subtitles even though many do not even speak Hindi underlines the popularity of such fares (see Advani, 2014; Raj \& Sreekumar, 2013).

Thomas Barker and Lee Yuen Beng (2017) meanwhile, outlined a series of issues linked to Malaysia's national CIs policy and made critical assessments of its relevance and implementation. One key issue is the lack of clarity in the policy's own definition of the term "creative" - the fact that "creative" seemed to cover a plethora of areas ranging from digital media to matters pertaining to the fine arts does raises some questions as to the potential of the policy has on developing creativity itself. In fact, they also asserted that the policy itself does not seem to focus on attempts at developing and cultivating creativity. Perhaps to add some context to this, for example, the FI is placed under the creative multimedia sector which itself consists of the film and television, advertising, design arts and animation and digital content, not to mention that there are 2 other wide-ranging "creative" sector (besides the creative multimedia) under the Malaysia CI umbrella ${ }^{23}$. In any case, much of the support provided under the NCIP since then is through the use of funding and/or technical skill building - while those are important, they may do little in harnessing creativity, which is really the essence of a creative sector like movie-making. That said, the use of tax/cash rebate as funding (e.g., in the case of the FIMI programme which started in 2013) is undoubtedly

\footnotetext{
23 They include crafts, visual arts, music, performing arts, creative writing and fashion and textiles under the Creative arts and culture sector while under the $\mathrm{CCH}$, the sub-sectors include those that are linked to national heritage like museums, archives, restoration and conservation (Arteri, 2018).
} 
a positive move, seeing that capital accessibility is a huge problem among the LFMs. Nonetheless, since its inception until 2015, there have been only 9 recipients among LFMs (3 annually from 2013-2015). In contrast, there were 26 foreign recipients over the same period (see FINAS Malaysia Annual Report, 2015 in Finas, 2018). While it still represents a positive development given that the conditions for foreign producers include clauses stipulating the involvement of local employees among others, the dearth of local producers benefitting from this should warrant further analysis ${ }^{24}$.

In addition, the issue of cultural discount is less pervasive in recent times, which explains why many FMs (especially American films) not only dominate their local box-office but are also hugely appealing to many Asian markets including Malaysia’s ${ }^{25}$. In any event, a big proportion of the Hollywood movies with wide releases worldwide have fairly universal themes like romance, action thriller, comic book adaptations and so on so it is not unusual that these movies would also resonate with worldwide audiences. In fact, studios, presumably to increase the bankability of their features, have known to even strategise to further narrow the cultural discount - these range from casting (e.g., having actors of different ethnicity to have more international appeal) to even having additional footages (or even minor plot enhancements), presumably to help pander to global audiences ${ }^{26}$. Further, Diana Crane (2014) argued that American films even incorporate themes and materials from movies of other countries while Laikwan Pang (2005) suggested that Hollywood's constant adaptation of works of other countries have led to significant foreign influences in the identity of its own movies leading to "transnational" movies ${ }^{27}$ - thus reinforcing the domination of Hollywood movies globally including in Malaysia.

Meanwhile, as far as production values (in monetary terms) are concerned, LFs are significantly lagging compared to foreign pictures. The average budget for a LF is only RM1.23 million (or in real terms, RM1.29 million - tabulated from Table 3's figures) which is only about half a million dollars. Such figure is miniscule compared to Hollywood standards in fact, this figure is even small when compared to low-budget Hollywood movies ${ }^{28}$. For instance, the average production budget for a movie in NA in 2008 was US\$22.96 million (Crane, 2014) while in Malaysia, RM1.46 million (equivalent to only US\$400.000 plus). In this sense, LF stands little chance in fending off foreign competition. Nonetheless, while there is little doubt of production budget being correlated to box-office success (i.e., greater budget

\footnotetext{
${ }^{24}$ At least $30 \%$ of the production crew must be Malaysia citizens or Malaysian permanent residents. Also, the production is required to employ interns as well (on top of the $30 \%$ production crew requirement), the number depending on the production budget.

${ }^{25}$ What is popular in one country may be the case in another due to differences in cultural values and social norms. As such, the appeal of cultural products like movies may be unpredictable when released in foreign markets (FMAs) (see Lee, 2008) for more.

${ }^{26}$ In the movie Iron Man 3 (director Shane Black, 2013), 4 minutes of extra footages featuring Chinese actors were added that were not in the US version. Also, some toning down on the ethnicity of the villain were done to make the film more appealing to Mainland Chinese audiences (see Daniel, 2013).

${ }^{27}$ A good example is the hugely successful Hong Kong police undercover movie Infernal Affairs (directors Andrew Lau, Alan Mak, 2002), which Hollywood remake in 2006 as The Departed (director Martin Scorsese) - the movie went on to win the Best Picture and Best Director at the 2007 Academy Awards.

${ }^{28}$ There is no clear definition for what is defined as a low-budget movie, in terms of production cost. In any case, the ten best low budget movies compiled by the New York Daily News for 2015 had budgets that ranged from \$US700.000 to \$US15 million (Lepore, 2015).
} 


\begin{tabular}{|c|c|c|c|c|c|c|c|c|c|c|c|c|c|c|c|c|c|c|c|}
\hline 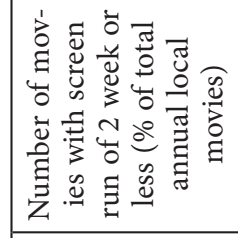 & $\frac{7}{\pi}$ & $\frac{\pi}{7}$ & $\frac{\pi}{d}$ & $e_{0}^{\circ} \int_{10}^{2}$ & 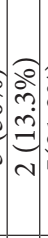 & (2) & & $\begin{array}{ll}0 \\
0 \\
0 \\
0 \\
0 \\
0\end{array} \mid$ & 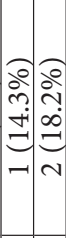 & 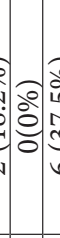 & 究 & $\left\{\begin{array}{l}\sqrt{2} \\
5 \\
0 \\
0 \\
0 \\
0\end{array}\right.$ & $=\frac{\pi}{a} \sqrt[\pi]{\frac{\pi}{a}}$ & & & 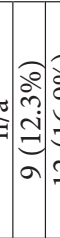 & 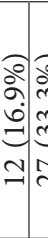 & 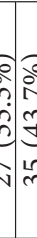 & 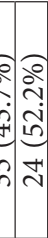 \\
\hline 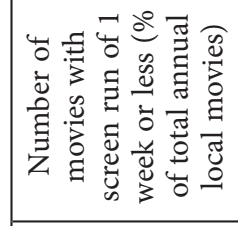 & $\frac{7}{\pi}$ & $\frac{\pi}{a}$ & $\stackrel{\pi}{\Rightarrow}$ & $\begin{array}{ll}0 \\
{ }^{\circ} \\
0\end{array}$ & $\begin{array}{l}2 \\
2 \\
6 \\
-1\end{array}$ & $\left(\begin{array}{ll}0 \\
\infty \\
\infty \\
\hdashline \\
\hdashline \\
m\end{array}\right.$ & & 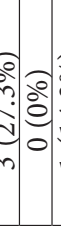 & 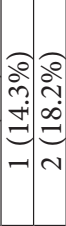 & $=$ & ㅎํㅇ & $e_{0}^{2}$ & $\frac{\pi}{2} \frac{\pi}{2}$ & & & $=$ & ही? & & 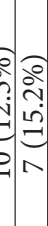 \\
\hline 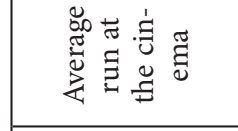 & $\stackrel{\pi}{a} \stackrel{\pi}{\beth}$ & $\frac{\pi}{a}$ & $\stackrel{\pi}{=} \frac{\pi}{\pi}$ & $\frac{\pi}{\sqrt[n]{n}}$ & & 2 & 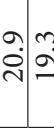 & $=$ & 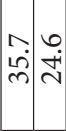 & 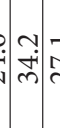 & 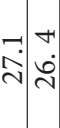 & : & $\frac{\pi}{a}=\frac{\pi}{z}$ & $\frac{\pi}{a}=\frac{\pi}{2}$ & & $=\underset{\sim}{ \pm}=$ & $\begin{array}{c}\hat{\lambda} \\
\vec{v}\end{array}$ & 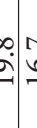 & $\dot{\Delta}: \stackrel{0}{\dot{N}}$ \\
\hline 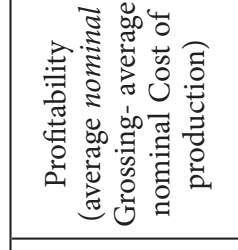 & $\stackrel{\pi}{a}=\frac{\pi}{2}$ & $\frac{\pi}{a}$ & & 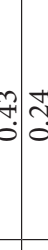 & $\frac{\pi}{a}$ & $\stackrel{\pi}{\beth}$ & & \begin{tabular}{lll}
$n$ & 0 \\
\hdashline & 0 \\
1 & 0
\end{tabular} & $\frac{\pi}{\vec{a}} \frac{\pi}{\vec{a}}$ & $\hat{n}$ & 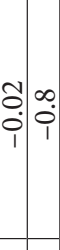 & $\dot{a}$ & 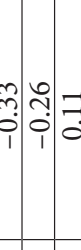 & $=$ & & $\stackrel{\pi}{b}=$ & 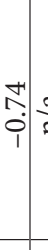 & $\frac{\pi}{3}$ & $\frac{\pi}{二}$ \\
\hline 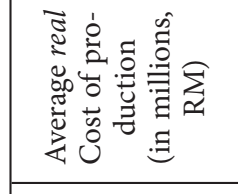 & ?: & $\frac{\pi}{\pi}$ & $\stackrel{\pi}{\beth}$ & $\begin{array}{l}\infty \\
+ \\
0\end{array}$ & $\frac{\pi}{a}$ & $\stackrel{\pi}{a}$ & $\stackrel{\pi}{a} ?$ & 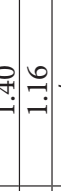 & $\stackrel{\pi}{a}=\frac{\pi}{a}$ & $=$ & 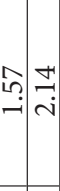 & $\stackrel{\frac{\pi}{a}}{=}$ & ક̊: & ְ: & & గُ & $\begin{array}{c}\infty \\
\infty \\
\infty \\
\end{array}$ & $\stackrel{\mathbb{a}}{5}$ & $\vec{y}$ \\
\hline 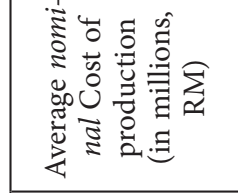 & $\overrightarrow{\tilde{0}}: \stackrel{\overbrace{}}{0}$ & $\frac{\pi}{\pi}$ & $\stackrel{\pi}{=} \stackrel{\vec{c}}{2}$ & $\begin{array}{c}\text { m. } \\
\text { m. }\end{array}$ & $\frac{\pi}{a}$ & ㄱ. & & 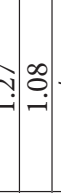 & $\stackrel{\pi}{a}=\frac{\pi}{\beth}$ & $\vec{n}$ & $\stackrel{\infty}{\stackrel{\circ}{-}}$ & 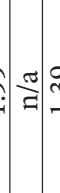 & ભેి & 워 & & & $\stackrel{+}{-}$ & & $\frac{\pi}{7}$ \\
\hline 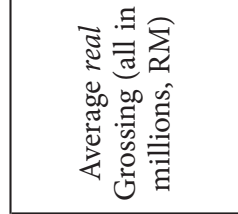 & $\stackrel{\pi}{a} \frac{\pi}{\beth}$ & $\frac{\pi}{a}$ & $\stackrel{\pi}{\beth}$ & : & 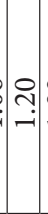 & م & $\begin{array}{ccc}0 & 0 \\
\infty & 0 \\
0 & 0\end{array}$ & $\begin{array}{c}\stackrel{n}{0} \\
\end{array}$ & గిరి: & 2 & 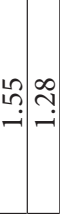 & 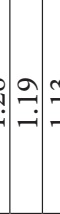 & $\stackrel{\Rightarrow}{\Rightarrow}=$ & อُ & 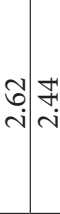 & ț & ŝ. & 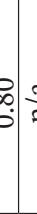 & 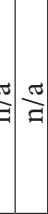 \\
\hline 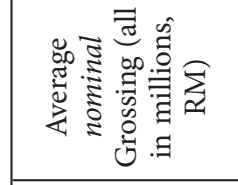 & $\stackrel{\pi}{\beth} \stackrel{\pi}{\beth}$ & $\frac{\pi}{a}$ & $\stackrel{\pi}{a} \infty$ & $\begin{array}{lll}\infty & \infty \\
\infty & \infty \\
0 & 0 \\
0\end{array}$ & $\stackrel{c}{\sigma}$ & ఏे & \begin{tabular}{l|l}
$R$ & $:$ \\
0 & th \\
0 & 0
\end{tabular} & 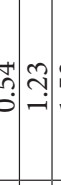 & în: & 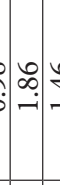 & 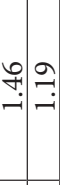 & $\Rightarrow$ & ְ: & 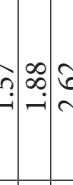 & 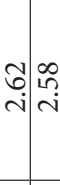 & 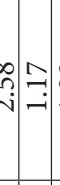 & 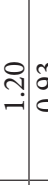 & & 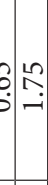 \\
\hline 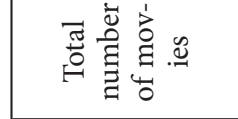 & & $\frac{\pi}{a}$ & & 은 & 10 & 0 & & $\exists \wedge$ & $\wedge \pm$ & $\therefore=$ & $\because \approx$ & 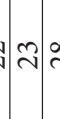 & iి & ำ & શે & $y$ & 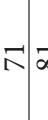 & & ? \\
\hline$\stackrel{\varpi}{\circlearrowright}$ & ஓे & $\vec{\Omega}$ & হั & รู) & $\frac{2}{2}$ & よे & ڤેప̆ & रิ & ஓे ఫે & 깅 & હి & 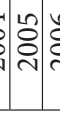 & ¿ેి & 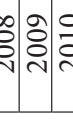 & 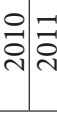 & בี & 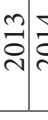 & & 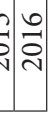 \\
\hline
\end{tabular}


indicates greater advertising outlays and naturally, more opening screens) there are still many countries making movies at costs much lower than Hollywood's and yet succeed - European movies are good examples; both Spanish and French movies have not only been very successful commercially but also prolific in international film awards/festivals as well. That said, even for a developed nation like France, its FI remains highly protected ${ }^{29}$, as is with the rest of Europe - cultural goods (movies included) are excluded from US-European Union trade negotiations. As such, while Hollywood movies can capture up to $80-90 \%$ of Latin America markets, its share of Western Europe is only 60-75\% while in France, further below 50\% (Hopewell, 2013). Interestingly, protectionism, albeit veiled, of the film sector extends to even in the US despite its superior comparative advantage in film-making ${ }^{30}$.

In terms of protection of markets, the LF sector in Malaysia has little protection in terms of quota or screen reservations for local fares. To the extent of it embracing an open market competition in the industry, such a move is at least, in economic theory, ensures an efficient market welfare outcome. On the other hand, this leads to FMs dominating the local circuit, as expected, given their comparative advantage thus stifling any hope for an infant industry to grow. While limiting protection may be undesirable, the opposite may not lead to a desirable outcome as well - in China, despite the heavy protectionism imposed (from import quotas of 20 films to revenue share of movie studios, with foreign studios' share of the box-office receipts limiting to only just $15 \%{ }^{31}$ ), FFs still dominate the local box-office. The experience of SK also revealed similar conclusions - protectionism does not work as planned. Jimmyn Parc (2017) argued that the recent success of SK cultural industries is not attributed to the country's history of protectionism policies - to the contrary, the policies actually hurt the industry. The early policy (1959-1986) of import quotas was based on LFMs making (and exporting) a certain number of movies in order to be entitled a quota of imports to be screened locally while the later policy (1966 onwards) was based on screen quotas, i.e., gazetting a fixed number of days for FMs' screening. Both, according to Parc (2017) have been detrimental to the sector in that they either lead to gaming the system (in the former, increasing local output just for the sake of meeting the quota to qualify for the rights to import) or indirectly hurting the sector (in the latter, the restricted days of screening only meant even tougher competition for LMs as only the best FMs are imported in order to maximize the returns from the limited window for foreign screening). Chung Insun (2018) also reported the detrimental impact of the import quotas to the SK FI before the mid-1980s liberalization - FFs' market share rose up to $80 \%$ despite the protectionist policies at the time.

In the context of Malaysia's experience, the intervention has been in the form of Skim Wajib Tayang in which all locally-produced movies are to be screened at local cinemas for a period of 14 days (Kamal, 2016; Finas, 2016). While such schemes are a welcome to LFMs but like the experience of screen quota in other countries (see Parc, 2017 in SK's case), this does

\footnotetext{
${ }^{29}$ Protectionism in the FI in France began immediately after the World War II with the government began imposing quotas on the importation of American films and reserving a certain number of weeks per screen for French films (see Brody, 2019).

${ }^{30}$ European film-makers have complained of veiled protectionism in the US against them (Cohen, 1993).

${ }^{31}$ Back home in America, studios' share is up to 55\% (The Economist, 2019). Nonetheless, the quota has been raised to 34 in 2012 (see Wyatt, Cieply, \& Barnes, 2012).
} 
not guarantee increase admissions. In fact, from the available data, we found that from 2012 to 2016, the average percentage of LMs having a run of 2 weeks (or even less) is around $40 \%$. More worryingly, the trend has been increasing every year - from $12 \%$ in 2012, the figure rose to $52 \%$ in 2016 (see Table 2). However, in 2005 (the year the minimum screening period was increased to 2 weeks), only 2 movies out of the 20 movies that were registered under the scheme ran for less than 2 weeks (i.e., 10\%) (FINAS Malaysia Annual Report 2005 in Finas, 2018, see Table 3). This shows a deteriorating trend as far as the effectiveness of the scheme is concerned - the minimum screen time fail to ensure greater attendance with a significant portion of the LMs only making the minimum run at the cinemas, as per the scheme. In fact, the average total run at the cinemas were much higher prior to 2005 despite the fact that back then the scheme only mandated a week of screening - from 1995 to 2004, the average run of LMs at the box-office was about 28 days. Also, from 1995 to 2004, the average percentage of local having a one week or less run at the cinemas was only $9.6 \%$ (see Table 3 ).

Finally, the more recent move by FINAS to subject LMs to "quality screening" was put into effect in July 2016, in which all LMs being mandated to seek approval from an evaluation panel and can only proceed to release subject to the greenlight from the panel. The panel would consist of representatives of Malaysian Association of Film Exhibitors and MFPA. Should a movie fail the assessment, it would be subjected to a second evaluation, with the evaluators being academicians, non-governmental organizations, journalists and fans (Kamal, 2016). Interestingly, such "quality screening", will also be the basis of a LF in receiving the greenlight for eligibility for the mandatory screening scheme. While quality is certainly crucial - a movie's success is ultimately driven by its quality (Vany \& Walls, 1999), ascertaining it before a movie's release is often difficult hence the famous quote by legendary Hollywood screenwriter William Goldberg, "With due respect, nobody knows anything" (Vany \& Walls, 1999), referring to the unpredictability of the industry. While the long-term effects of this move is difficult to assess at this junction, intuitively at least, the move may be counterproductive in that first, quality is difficult to assess (what more, box-office success) and secondly, film-makers may be reluctant to be subjected to such scrutiny. In any case, it may make more sense to assess a film's potential prior to its production, i.e., evaluating its plot, film-makers involved and so on. This way, it would avoid any embarrassment to film-makers with an already finished article but rejected nonetheless, presumably over quality issues ${ }^{32}$. In any event, the issue of defining quality from the perspective of regulators was criticised in Parc (2017), lamenting the weakness of the import quota era in SK's FI in which the highquality reward system was eventually replaced due to endless disputes over quality ${ }^{33}$.

\footnotetext{
32 A good example is the practice by the Lithuanian Film Center (LFC) - as part of the public policy on state fund eligibility for LFMs, the LFC must first assess the film project's potential, this ranging from evaluating the film's plot to the personnel involved and even to the execution of the project as well. The LFC's establishment has been credited by some as a pivotal move in helping strengthen and shape the competitiveness of the Lithuanian FI (for more, see Mitkus and Nedzinskaite-Mitké, 2017).

${ }^{33}$ In this scheme (from 1959-1986), only successful players which produce and export SK movies be rewarded with the rights to import films. Presumably, only high-quality movies could be exported (for more, see Parc, 2017).
} 


\section{Concluding remarks}

Assessed over a broader context, the local FI is struggling to compete against foreign competition. While the regulators in the country have in place several policies to bolster the industry, the impact has been mixed - despite film activity and income generation as a whole has increased, LFs have not been able to mount a sustained challenge against imported FFs in the DM. Currently, the tax rebate scheme for film-making does not discriminate against FFMs - quite the contrary, it encourages more foreign participation in film-making activities in the country. While this is a good move (already proven so given the amount of films, foreign ones, being shot and post-produced in the country), it nevertheless, does little to alleviate the LFMs' position in the marketplace as far as competing against FMs is concerned, at least evidence from the data shows. Similarly, the mandatory screening scheme for LMs, while ensuring a minimum window for box-office collection, does not ensure admission thus may explain the huge percentage of LMs which only satisfy the minimum mandatory screen run of 2 weeks. Unsurprisingly, the then director-general of FINAS has called for a review on the compulsory scheme stating that the scheme is not effective enough as far as raising the quality of movie is concerned (Palansamy, 2016). While much has been debated over the issue of the quality of LMs - a definitive solution remains elusive. Besides the issue of quality, the lack of financial investment in film-making is another problem - the recent tax rebate scheme helps but on the whole, LM budgets are still very low in comparison to those from overseas. The fact that the average budget for a local fare is akin to what would generally be considered as a low-budget film in the US suggest that local fares are of no match for imported films, especially in technology and marketing matters. As such, local policymakers may need to bolster their support in marketing and selling of LMs to foreign distributors to increase earnings.

Nonetheless, the recent spate of hit LMs is encouraging especially with some of them being non-Malay fares which are presumably directed at the other ethnic groups - this indicates a more diversified sector as compared to the past whereby the LMs are dominated be Malay movies aimed mostly at the Malays. Such development is perhaps crucial since the invasion of FMs are not only restricted to Hollywood movies but also those from Hong Kong/China/ Taiwan and Bollywood which are targeted at the other main ethnic groups in the country as well. With the rise of SK and even Thailand movies, the market is especially crowded and competition stiff thus the challenge for the local regulators to safeguard LM participation and success is even greater. In fact, going by recent trends, Hollywood are more interested in FMAs than ever, seeing that many of the their blockbusters accounting significantly more in foreign grossing than that of its own DM - with breakdown figures going to up $20 \%-80 \%$ (i.e., $80 \%$ of the grossing coming from IMs) being common among many Hollywood event movies in recent times ${ }^{34}$.

34 In recent times, such pattern has been seen in big movies like The Mummy (director Alex Kurtzman, 2017), Warcraft (director Duncan Jones, 2016) and Terminator Genisys (director Alan Taylor, 2015), to name a few. Each of these movies' box-office grossing had at least $70 \%$ or more contribution from overseas markets, with $80 \%$ in the case of Warcraft (figures quoted from author's own tabulation from data at Box Office Mojo, 2019a). Previously, US markets normally accounts for half the total box-office grossing. 
In any event, the very characteristic of the movie industry itself (i.e., driven by positive information feedback which basically means that success will ignite even more success and vice versa (see Vany \& Walls (1996) for more on why such winner-takes-all markets would lead to disproportionate earnings amongst the players) would entail that Hollywood movies to dominate many LMAs, presumably due to their vastly superior film technology and marketing prowess. This should not come as a surprise - even with a casual assessment of the market landscape in many countries, few would argue against such conjectures. Nonetheless, in some countries, local fares have, to various degrees, been able to produce commendable box-office results even in the face of such foreign competition. Walls (2009) reported that despite a field that is crowded with Hollywood box- office winners, some of the Thailand fares have proved to be even bigger than its Hollywood counterparts - despite a list filled with Hollywood blockbusters, the 2 top box-office earners in Thailand from 2004-2008 were in fact, local Thailand films (Walls, 2009). Even more convincingly, in China (albeit direct quota protections), LMs have clear strides in the movie market - from 2009 onwards, the market share of the local Chines films at the box-office has surpassed the imported ones and the gap has been rising is steadily from 2013-2015 (Richeri, 2016). In fact, Chinese filmmakers have managed to produce their own home blockbusters which have gone on to make huge amount of money at the LM circuit, figures that are comparable to the biggest domestic grossers at the NA box-office. For instance, Wolf Warrior 2 (director Wu Jing, 2017) made US\$854 at the Chinese box-office - a figure which would have placed it second among the biggest grossing movies at the NA market ${ }^{35}$. In comparison, Malaysia's LMs still lag significantly behind its foreign competitors at the box-office achievement (see Tables 1, 2 for comparison between the annual top grosser local and FMs in Malaysia from 2008-2016). However, recent performance does suggest some catching up is taking place - 2018 saw 3 LMs raking in excess of RM30 million, a figure that is unheard of even up to 2017 and ranked among the top movies for 2018 even with the inclusion of $\mathrm{FMs}^{36}$. Nonetheless, it remains to be seen if such achievements can be sustained.

To conclude, although several policies have and are currently in place to stimulate the Malaysian FI, including financial assistance, the crux of the problem may lie more on the quality of the product (which is the result of scarcity of talent) which unfortunately, is an issue that the current policies, in the form of mandatory screenings and/or subsidies (rebates and loans) are unlikely to resolve. As pointed out by Barker and Yuen Beng (2017), the local creative policies seem more directed at funding and providing support for technical skills (e.g., multimedia aspects of film-making) but not addressing the issue of creativity itself, which, in the context of the FI, would encompass issues like scripting, creative storytelling incorporating local culture and so on. Subsidy, of course would help, even pivotal to a large extent, as seen in the case of many other countries including devel-

\footnotetext{
${ }^{35}$ As of end May 2019, only Star Wars: The Force Awakens (director J. J. Abrams, 2015) has grossed more in the North American box-office. Further, in recent years, there have been a spate of local blockbusters at the Chinese market; Operation Red Sea (director Dante Lam, 2018; \$575.849.199), Detective Chinatown 2 (director Chen Sicheng, 2018; \$541.406.438), The Mermaid (director Stephen Chow, 2016; \$526.848.189) and The Wandering Earth (director Frant Gwo, 2019; \$690.994.017) to name a few (figures taken from Box Office Mojo, 2019b).

${ }^{36}$ Munafik 2 (director Yusof, 2018), Hantu Kak Limah (director Mamat Khalid, 2018) and PASKAL: The Movie (director Adrian Teh, 2018) grossed RM37.74 million, RM36.23 million and RM30 million respectively (Finas, 2019d).
} 
oped ones with superior film making track record (e.g., New Zealand, US, United Kingdom (UK), Australia and a host of European countries) but perhaps a more sophisticated and better-incentivised set of state funding support may be needed in order to ensure the industry's progress and competitiveness against foreign imports ${ }^{37}$. In any event, the bigger core of the problem may lie on the subsequent more narrowed focus and pursuit of the NCIP since its much touted inception - i.e., addressing creative issues from an economic viewpoint (hence the various agencies in funding provision) rather than from a more wider cultural and social lens (e.g., pursuing the appropriate policy and regulatory reforms on the media landscape or harnessing local culture and identity into COs) not to mention the inefficiencies associated with the use of financial assistance (e.g., there have been projects of questionable "creative" value receiving funding - see Barker \& Yuen (2017) for more on this) ${ }^{38}$. Perhaps unsurprisingly, the fact that the CI encompasses three wide-ranging sectors (and their subsequent respective sub-sectors) is always going to be challenging in some sense when addressed under the umbrella of a sole national policy on $\mathrm{CIs}^{39}$. Finally, as far as the FI is concerned, the policymakers must also consider the long-term strategy and direction of the industry, this includes not just on how best to support film-makers (especially new ones) in terms of improving their CO but also financially - disbursement of loans or grants is pivotal but equally so for the film-makers to understand the business side of making movies ${ }^{40}$. This is especially so given that profitability, on average, is still very low in the industry (see Table 3). Ultimately, there may be a need to go back to the drawing board and learn from the success (and failures) of the creative and cultural policies of other countries.

\footnotetext{
${ }^{37}$ For example, in France, special funds are available directors who are considered to have artistic merits while first time directors are also entitled to them. Even the location of the film shoot is considered (see Jäckel, 2007; Scott, 2000).

${ }^{38}$ Note that the definition of the creative industry in Malaysia is any industry that (i) involves creative individuals, (ii) identify, encourage and showcase talent (on an individual or group level), (iii) use technology for innovation aimed at economic success contributing to the national gross domestic product and (iv) focus on work and intellectual property in line with the cultures and values of the various races in Malaysia (Arteri, 2018). In any event, the outcome of any policies, whether market-based improvements (e.g., regulatory overhauls), interventionist (e.g., rebates or subsidies) or infrastructure building (e.g., facilities for creative activities), should ideally be directed at cultivating more COs (e.g., greater appreciation of local culture or having a more conducive ecosystem leading to the generation of more critically appraised/“successful” COs) (for a critical assessment on the NCIP, see Barker \& Yuen Beng, 2017).

${ }^{39}$ In any case, when initially launched, the list of objectives under the NCIP enlisted to chart the sector's direction include the following (i) to become a dynamic creative sector contributing to the nation's economy, playing its part to help Malaysia become a high-income nation, (ii) to support the development of the CI into one that is competitive, advanced and sustainable at a national and international level, (iii) to prepare the facilities, infrastructure, and create a conducive environment to encourage the growth of the local CI, (iv) to spur on the growth and recognition of intellectual property in the CI through training programmes and accreditation, (v) to develop and harness technology as a catalyst for industrial growth and, (vi) to grow information sources, focus on local cultural symbolism, and national identity in the CI on a global level (Arteri, 2018).

${ }^{40}$ Issues plaguing the industry were raised by several successful LFMs include the high cost of distribution and advertising, mounting loan debts post film failures and finally, the issue of education - the failure of the system to enrich students with visual and cultural literacy (Wie Boon, 2016). In the case of marketing and distribution cost issues, even film producers in the UK struggle to overcome such barriers - many productions rely on US film companies for distribution and even financing (Crane, 2014).
} 


\section{References}

Advani, R. (2014). India's popular culture in Southeast Asia. ISAS Working Paper 148. Retrieved from https://www.isas.nus.edu.sg/wp-content/uploads/media/isas_papers/ISAS_Working_Paper_ No._198_-_India\%27s_Popular_Culture_in_Southeast_Asia_08102014200937.pdf

Arteri. (2018). National Creative Industry Policy (DIKN). Retrieved from https://www.arteri.com.my/ learn/policies/dikn/

Aziz, J., Hashim, H., \& Ibrahim, F. (2014). Malaysian film industry in transformation: challenges and potential. Malaysian Journal of Communication, 30(1), 37-51. https://doi.org/10.17576/JKMJC-2014-3001-03

Aznam Shah, Sh. (2017). Local films struggle at the box office. The Malaysian reserve. Retrieved from https:/themalaysianreserve.com/2017/10/10/local-films-struggle-box-office/

Barker, Th., \& Yuen Beng, L. (2017). Making creative industries policy: The Malaysian case. Kajian Malaysia, 35(2), 21-37. https://doi.org/10.21315/km2017.35.2.2

Begum, M. (2016). Finas Revises Skim Wajib Tayang Star2.com. Retrieved from https://www.star2.com/ entertainment/2016/03/31/finas-revises-skim-wajib-tayang/

bnm.gov.my. (2018). Economic developments in 2018. Retrieved from http://www.bnm.gov.my/files/ publication/ar/en/2018/cp01.pdf

Box Office Mojo. (2019a). Box office Mojo. Retrieved from https://www.boxofficemojo.com/

Box Office Mojo. (2019b). China yearly box office. Retrieved from https://www.boxofficemojo.com/intl/ china/yearly/

Box Office Mojo. (2019c). Malaysia yearly box office. Retrieved from https://www.boxofficemojo.com/ intl/malaysia/yearly/

Brody, R. (2019). The future of French cinema. The New Yorker. Retrieved from https://www.newyorker. $\mathrm{com} /$ culture/richard-brody/the-future-of-french-cinema

Chee Kit, L., \& Weng Chuan, L. (2012). Hollywood films and local films: a quantitative study on Malaysian young generations' preference. Procedia: Social and Behavioral Sciences. Retrieved from https:// www.academia.edu/6125886/Hollywood_Films_and_Local_Films_A_Quantitative_Study_on_Malaysian_Young_Generations_Preference

Cohen, R. (1993). France and Spain impose quotas. The New York Times. Retrieved from https://www. nytimes.com/1993/12/22/movies/france-and-spain-impose-quotas.html

Crane, D. (2014). Cultural globalization and the dominance of the American film industry: cultural policies, national film industries, and transnational film. International Journal of Cultural Policy, 20(4), 365-382. https://doi.org/10.1080/10286632.2013.832233

Daniel, J. (2013). Iron Man 3 execs "Changed film for Chinese audience" by adding four minutes to the film with Chinese actors. Mail online. Retrieved from https://www.dailymail.co.uk/news/ article-2324077/Iron-Man-3-execs-changed-film-Chinese-audience-adding-4-minutes-Chineseactors.html

FIMI. (2017). FIMI. Retrieved from http://www.filminmalaysia.com/?option=com_content\&view=art icle\&id=93\&Itemid $=605$

Finas. (2019a). Corporate info. Retrieved from https://www.finas.gov.my/en/introduction/

Finas. (2019b). Data of cinema admission by language. Retrieved from https://www.finas.gov.my/en/ industry-information/cinema-admission-by-language/

Finas. (2019c). Malaysian box office. Retrieved from https://www.finas.gov.my/en/malaysian-box-office/

Finas. (2019d). Top 50 feature film. Retrieved from https://www.finas.gov.my/en/industry-information/ top-50-feature-film/ 
Finas. (2016). Finas. Retrieved from https://www.finas.gov.my/

Finas. (2018). Malaysian annual reports, 1983-2016. Retrieved from https://www.finas.gov.my/en/ annual-report/

Hopewell, J. (2013). Hollywood stymied as Europe sticks with its limits on film and TV. Variety. Retrieved from https://variety.com/2013/film/global/hollywood-stymied-as-europe-sticks-with-itslimits-on-film-and-tv-1200497446/

Hoskins, C., \& McFadyen, S. (1991). International marketing strategies for a cultural service. International Marketing Review, 8(2). Retrieved from https://www.emeraldinsight.com/doi/pdfplus/10.1108/02651339110145117

Insun, Ch. (2018). Risk or chance: "The liberalization of foreign film imports" and its impacts in Korea and Japan. International Journal of Cultural Policy, 24(1), 68-84. https://doi.org/10.1080/10286632.2015.1116525

Jäckel, A. (2007). The inter/nationalism of French film policy. Modern \& Contemporary France, 15(1), 21-36. https://doi.org/10.1080/09639480601115268

Kamal, H. A. (2016). What's wrong with local movies? New straits times. Retrieved from https://www. nst.com.my/news/2016/01/120115/whats-wrong-local-movies

King, T. (2007). Does film criticism affect box office earnings? Evidence from movies released in the U.S. in 2003. Journal of Cultural Economics, 31(3), 171-186. https://doi.org/10.1007/s10824-007-9041-z

Koay, A. (2014). Malaysia's ever-growing entertainment industry. Retrieved from https://www.thestar. com.my/lifestyle/entertainment/tv/news/2014/07/31/evergrowing-industry/

Lee, F. L. F. (2008). Hollywood movies in East Asia: examining cultural discount and performance predictability at the box office. Asian Journal of Communication, 18(2), 117-136. https://doi.org/10.1080/01292980802021855

Lepore, S. M. (2015). The biggest low-budget hits of 2015. New York Daily News. Retrieved from https:// www.nydailynews.com/entertainment/2015-low-budget-hits-article-1.2359590

Malek, N. H. A. (2019). Malaysian movies gross over RM150 $\mathrm{m}$ in 2018. Malaysian reserve. Retrieved from https://themalaysianreserve.com/2019/01/04/malaysian-movies-gross-over-rm150m-in-2018/

Mitkus, T., \& Nedzinskaitè-Mitkè, V. (2017). Promoting competitiveness in creative industries: changes and trends of Lithuanian film industry in 21st century. Creativity Studies, 10(1), 14-25.

mpaa.org. (2018). 2018 THEME report. Retrieved from https://www.mpaa.org/wp-content/uploads/2019/03/MPAA-THEME-Report-2018.pdf

Ortman, Ch. (2019). New report: global theatrical and home entertainment market reached $\$ 96.8$ billion in 2018. News. Retrieved from https://www.mpaa.org/press/new-report-global-theatrical-andhome-entertainment-market-reached-96-8-billion-in-2018/

Oxford Economics. (2013). The economic contribution of the film and television industries in Malaysia. Retrieved from https://www.mpa-i.org/wp-content/uploads/2014/08/Msia_2013.pdf

Palansamy, Y. (2016). Finas DG calls for review of Putrajaya's mandatory screening policy. Malay mail. Retrieved from https://www.malaymail.com/news/malaysia/2016/07/10/finas-dg-calls-for-reviewof-putrajayas-mandatory-screening-policy/1158891\#QwT4AX02vyVjV6GY.97

Pang, L. (2005). Copying Kill Bill. Social Text, 23(2), 133-153. https://doi.org/10.1215/01642472-23-2_83-133

Parc, J. (2017). The effects of protection in cultural industries: the case of the Korean film policies. International Journal of Cultural Policy, 23(5), 618-633. https://doi.org/10.1080/10286632.2015.1116526

Raj, S. J., \& Sreekumar, R. (2013). Desi turns malay: indian cinema redefined as crossover in the Malaysian market. In S. Khorana (Ed.), Crossover cinema: cross-cultural film from production to reception. Series: Routledge Advances in Film Studies (pp. 153-166). New York and London: Routledge. 
Richeri, G. (2016). Global film market, regional problems. Global Media and China, 1(4), 312-330. https://doi.org/10.1177/2059436416681576

Rosnan, H., \& Abdul Aziz, Z. D. (2012). Film business in Malaysia: challenges and opportunities. International Journal of Humanities and Social Science, 2(12), 198-202.

Scott, A. J. (2000). French cinema: economy, policy and place in the making of a cultural-products industry. Theory, Culture \& Society, 17(1), 1-38. https://doi.org/10.1177/02632760022050988

The Economist. (2019). Hollywood goes global: bigger abroad. Retrieved from https://www.economist. com/business/2011/02/17/bigger-abroad

US Inflation Calculator. (2019). Consumer price index data from 1913 to 2019. Retrieved from https:// www.usinflationcalculator.com/inflation/consumer-price-index-and-annual-percent-changes-from1913-to-2008/

Vany, De A., \& Walls, W. D. (1996). Bose-Einstein dynamics and adaptive contracting in the motion picture industry. The Economic Journal, 106(439), 1493-1514. https://doi.org/10.2307/2235197

Vany, De A., \& Walls, W. D. (1999). Uncertainty in the movie industry: does star power reduce the terror of the box office? Journal of Cultural Economics, 23(4), 285-318. https://doi.org/10.1023/A:1007608125988

Vogel, H. L. (2011). Entertainment Industry economics: a guide for financial analysis. Cambridge: Cambridge University Press.

Walls, W. D. (2009). The market for motion pictures in Thailand: rank, revenue, and survival at the box office. International Journal of Business and Economics, 8(2), 115-131.

Wie Boon, S. (2016). Lights, camera, Malaysia: why the Malaysian film scene has been in a slump, yet everyone wants to be a director. Esquire. Retrieved from https://www.esquire.my/culture/We-delveinto-the-state-of-the-local-film-industry

Wyatt, E., Cieply, M., \& Barnes, B. (2012). U.S. Scrutinizes Hollywood Deals in China. International Herald tribune. Retrieved from https://www.questia.com/read/1P2-36284803/u-s-scrutinizes-hollywood-deals-in-china

XE. (1995-2019). XE currency charts: USD to MYR. Retrieved from https://www.xe.com/currencychar ts/?from $=$ USD\&to $=$ MYR\&view $=2 Y$

Yoong Hon, L. (2014). Experts versus audience's opinions at the movies: evidence from the North American box-office. Marketing Bulletin 25. Retrieved from http://marketing-bulletin.massey.ac.nz/ V25/MB_V25_A1_Hon_FINAL.pdf

\title{
MALAIZIJOS KŪRYBINIŲ INDUSTRIJŲ VERTINIMAS: KINO INDUSTRIJOS PAŽANGA IR POLITIKA
}

\author{
Lee YOONG HON, Ruth LIM SHEAU YEN
}

\section{Santrauka}

Straipsnyje nagrinejamos vietos kino filmų charakteristikos Malaizijos komercinių imonių atvejais, siekiant nustatyti ir išanalizuoti patobulinimų, apie kuriuos buvo oficialiai paskelbta, sektoriaus mastą - tikimasi, kad gauti duomenys gali suteikti kur kas objektyvesnị vietos kino filmų ịvertinimą ir apibrèžti politiką, nukreiptą ị šio sektoriaus patobulinimus. Apibendrinti duomenys rodo, kad vietos kino industrijai reikia dar daug nuveikti, kad įsitvirtintų net savo vietos rinkoje.

Reikšminiai žodžiai: komercinè įmone, kultūros politika, užsienio kino filmai, vietos kino filmai, Malaizijos kino industrija. 